\title{
研究課題別事後評価結果
}

1. 研究課題名

遺妘子の不活化・活性化を通した植物の生体制御

2. 研究代表者名及び主たる研究参加者名（研究機関名・職名は研究参加期間終了時点）

研究代表者者橋 祐子 独立行政法人・農業生物資源研究所 特待研究員

主たる研究参加者 角谷 徹仁 国立遺伝学研究所 助教授

佐野 浩＼cjkstart奈良先端科学技術大学院大学 教授

3. 研究内容及び成果

植物は病傷害に対する独自の自己防御機構を有している。この機構を研究し、遺伝子組換えにより人為的に 植物の自己防御力を強化させた植物を作ることが出来れば、それは省農薬・省労力で育つ耐病性・耐ストレス 植物となる。このような有用植物は地球環境の保全や食糧増産のために必要であり、その作出に関する基礎研 究の進展が期待されている。しかし、外来遺伝子を導入して有用植物を作っても、導入遺伝子が徐々に働か なくなる “遺伝子不活化現象” が頻繁に起こるので問題となっている。また、一度不活性化した遺伝子がまた 働くようになる現象も知られている。この問題を解決するために植物における遺伝子の不活化・活性化の機構 を明らかにし、得られた知見を安定した有用組換え植物作出に役立てようと考えた。本研究はこの分野で研究 実績のある3グループにより、以下のように課題を分担して行われた。

植物における遺伝子の不活性化には、主にプロモーター領域がメチル化される「転写抑制型タイプ

(TGS)」と、転写が起こっているのにmRNAが分解される「転写後タイプ(PTGS)」が知られる。大橋グル 一プが植物特有の自己防御機構である過敏感細胞死とこれに伴う誘導抵抗性の機構を “遺伝子の活性化 · 不活 性化"といつた点からとらえて研究すると共に、導入遺伝子のPTGSの機構を解析した。角谷グループはDNA のメチル化による遺伝子の不活性化を“メチル化の变異株”を用いて分子遺伝学的に解析し、また、佐野グル 一プは“植物におけるDNAメチル化の機構とその意義を明らかにする゙ため独自の系を用いて研究を行った。 ここで得られた研究成果は多くの重要新規知見を含み、植物の自己防御機構が個体、組織、細胞のみならず核 酸レベルでも巧妙に制御されていることを示した。これらの知見は、外来・内在遺伝子の発現制御技術のみな らず、有用組換え植物作出のために役立てられる。

\section{[大橋グループ ]}

過敏感細胞死は、病原体に感染した細胞の自殺であり、病原体を感染部位に局在化させ全身に蔓延させない ための植物特有の自己防御機構である。この細胞死は、生き残つた健全組織を再感染から守るため、植物体全 身にさらなる病害抵抗性を誘導する。この全身獲得抵抗性は、高等動物のような免疫系を持たない植物にとつ て大変重要である。同調的な過敏感細胞死誘導系を用い、細胞死が起こる前にその発現が抑制あるいは活性化 される遺伝子の機能解析を行い、過敏感細胞死には、光合成装置である葉緑体が重要な働きをすること、カル モジュリンが誘導抵抗性に関与することなど、多くの新規知見を得た。また、全身抵抗性誘導のシグナル物質 とされるサリチル酸が、PTGSを誘発させることでウイルス核酸の特異的分解を促進しウイルス抵抗性を誘導 すること、を発見した。さらに、いままでPTGSがその植物当代限りの現象で後代には伝わらないことの原因 は“減数分裂ないしは受精などの特定のステージで解除される゙ためと言われていたが、実は “PTGSは細胞分 裂によってリセットされ、種子では生殖細胞に分化する以前に行われていた活発な細胞分裂によってPTGSが すでに解除されており、PTGSが伝えられる前に親細胞から隔離されるために、次世代にPTGSが伝わらな い"ことを示した。

\section{[角谷グループ $]$}

DNAメチル化を伴う遺伝子不活性化を解除するシロイヌナズナ突然変異ddm1(decrease in DNA methylation)を用いて、植物におけるDNAメチル化と遺伝子不活性化の役割を調べた。この突然変異下で誘 導される発生異常を遺伝解析することにより、ddm1突然変異下で特異的に転移するトランスポゾンCAC1 と、この突然変異下で異所的に発現して発生異常を引き起こす遺伝子FWAを同定した。これによって、DNA メチル化を伴う遺伝子不活性化が、植物遺伝子の適切な発現を保証するだけでなく、トランスポゾンを抑制す ることによりゲノム構造の維持にも貢献することが明らかにできた。現在この研究は、遺伝子不活性化に影響 する種々の突然変異や遺伝環境におけるCAC1とFWAの活性解析へと進展している。これらの研究によって、 
「epigeneticな遺伝」（塩基配列の変化を伴わない染色体情報の遺伝）の「ゲノム防御」と「個体発生」にお ける役割の分子レベルでの解明を達成しつつある。

\section{[佐野グループ $]$}

高等動植物のDNAは修飾塩基として 5 -メチルシトシンを含む。その量は高等植物では全塩基の 3 - 7 \%に及 ぶ。生理作用にはまだ不明の所が多いが、主に遺伝子の発現調節に関与し、植物の自己防御に働いている可能 性が指摘されている。ここでは “DNAメチル化の生理作用”を総合的に理解するために、以下に示すような 課題をたて多くの成果を得た。（1）緑藻の葉緑体の母性遺伝のしくみの解析：DNAのメチル化により制御 されていることを証明、（2）植物からの 3 種のDNAメチル化酵素遺伝子の単離とその特性解析、メチル化 DNAの生理機能解析、（3）環境変化に応答したDNAメチル化レベルの変動と遺伝子発現制御、（4）DNAX チル化の人工操作による有用植物の分子育種。これらの結果は、最近、注目を集めている epigenetic 遺伝の 植物における実態を明らかにしたもので、角谷グループの成果とあわせ、実用的な分子育種にも応用可能な重 要な知見を含んでいる。

4. 事後評価結果

4-1. 外部発表(論文、口頭発表等)、特許、研究を通じての新たな知見の取得等の研究成果の状況

上述の成果は、英文論文 65 件、和文論文 21 件として発表されている。その主要なものは、Nature 1 報、Plant Cell 2 報、Proceedings of the National Academy of Sciences, USA 1 報、Trends in Plant Science 2 報、Current Biology 1 報、Journal of Biological Chemistry 1 報、Nucleic Acid Research 3 報、Plant Journal 4報、Plant Physiology 3 報、Biochemical Journal 1 報、Genetics 2 報等で、質量共 に高く評価できる。過敏感細胞死、全身獲得抵抗性、PTGS等のメカニズムの解明、シロイヌナズナを用いて ジーンサイレンシングに関与する因子、CAC1とFWAの同定、葉緑体DNAのメチル化酵素遺伝のクローニング とこれがシトシンメチル化酵素であることを確認するなど、国内は勿論、国際的にも評価される成果である。

学会での発表は、国内101件、国際会議で52件なされたが、特許は国内出願 1 件にとどまった。植物におけ るDNAメチル化と遺伝子不活性化の役割を調べたNatureの論文に関して、2001年5月16日の朝日新聞にて報 道された。

\section{$4-2$. 成果の戦略目標・科学技術への貢献}

植物特有の自己防御機構である過敏感細胞死とこれに伴う誘導抵抗性のメカ二ズムを研究し、過敏感細胞死 には葉緑体が重要な役割を果たしていること、カルモジュリンが誘導抵抗性に関与していること等を明らかに した他、導入遺伝子の不活化機構を解析し、外来遺伝子の不活性化が細胞増殖により回復すること、DNAX チル化を伴う遺伝子不活性化はトランスポゾン抑制のための自己防御であること等の知見を得た。これらは、 植物での外来遺伝子導入、発現を人為的に制御する技術開発にとって重要と思われる。

$4-3$. その他の特記事項

研究代表者は「耐病性植物育種の分子基盤研究」で、2002年度生物系特定産業技術研究推進機構の「新技 術・新分野創出のための基礎研究推進事業」に採択された。

$\leq<$ 生体防御トップ

This page updated on September 12, 2003 Copyright(C)2003 Japan Science and Technology_Corporation 